\title{
Return migration of adult Atlantic salmon (Salmo salar L.) to northern Norway
}

\author{
Eva Marita Ulvan ${ }^{1 *}$, Anders Foldvik ${ }^{1}$, Arne Johan Jensen ${ }^{1}$, Bengt Finstad ${ }^{1}$, Eva Bonsak Thorstad ${ }^{1}$, \\ Audun Håvard Rikardsen ${ }^{2}$, and Tor Fredrik Næsje ${ }^{1}$ \\ ${ }^{7}$ Norwegian Institute for Nature Research (NINA), PO Box 5685 Torgarden, NO 7485 Trondheim, Norway \\ ${ }^{2}$ Department of Arctic and Marine Biology, UiT - The Arctic University of Norway, NO 9037 Tromsø, Norway
}

*Corresponding author: tel: +479940 92 96; fax: +4773801481; e-mail: eva.ulvan@nina.no

Ulvan, E. M., Foldvik, A., Jensen, A. J., Finstad, B., Thorstad, E. B., Rikardsen, A. H., and Næsje, T. F. Return migration of adult Atlantic salmon (Salmo salar L.) to northern Norway. - ICES Journal of Marine Science, doi:10.1093/icesjms/fsx183.

Received 3 April 2017; revised 4 July 2017; accepted 18 August 2017.

The return migration of adult Atlantic salmon was investigated by analysing recaptures of individuals tagged and released as smolts in the River Altaelva and the River Halselva using a catch per unit effort approach. Although the salmon were recaptured over a large area along the coastline (from $>1100 \mathrm{~km}$ south to $>500 \mathrm{~km}$ northeast of their home rivers), the results indicated a relatively accurate homeward navigation for most individuals. The straying rate to rivers other than the home river was $9 \%$. Multi-sea-winter salmon returned earlier in the season than one-sea-winter salmon, but the geographical distribution of recaptures did not differ. Recaptures were equally distributed north and south of the home rivers, implying that salmon were arriving to the coast both north and south of their home rivers and that they may have returned from different ocean areas. This was supported by the fact that several salmon were recaptured in both the southern and northern parts of the North Atlantic Ocean, including at the Faroes, south coast of Greenland, Svalbard and in the Barents Sea. This study supports the hypothesis that the coastal phase of the natal homing in migrating fish species is neither passive nor guided by currents alone.

Keywords: Atlantic salmon, coastal areas, CPUE, return migration.

\section{Introduction}

Regular long-distance migrations are found in most groups of animals, like mammals, birds, fishes, crustaceans and insects (Dingle, 2014; Secor, 2015). This includes anadromous fishes like salmonids, which spawn in fresh water where their offspring live as juveniles, before they smoltify and migrate to sea to take advantage of increased food-availability (Gross et al., 1988). This marine feeding migration is short for some species, like brown trout (Salmo trutta L.) and Arctic char (Salvelinus alpinus L.), lasting the summer months before they return to fresh water to spawn and/or overwinter (Klemetsen et al., 2003; Jensen et al., 2015). Other salmonids, like Atlantic salmon (Salmo salar L.) and most species of Pacific salmon (Oncorhynchus spp.) remain for one to seven years in the ocean before they return to spawn (Groot and Margolis, 1991; Klemetsen et al., 2003).

Anadromous salmonids are known for their accurate ability to return to their natal river after ocean feeding migration (Thorpe,
1988; Keefer and Caudill, 2014). Homeward migration of Atlantic salmon consists of two main phases: first from the ocean feeding areas to the coast, and then through coastal waters and fjords to the rivers (Hansen et al., 1993; McCormick et al., 1998; Lohmann et al., 2008; Ueda, 2012; Petersson, 2016). For open ocean navigation, mechanisms such as a map-and-compass system, geomagnetism, visual cues, and rheotaxis in relation to oceanic currents have been suggested. The pheromone hypothesis implicates that returning salmonids are able to recognize and navigate by population-specific pheromones emitted by outward migrating smolts (Nordeng, 1977). Another, generally more accepted, hypothesis is the olfactory imprinting hypothesis. Prior to their seaward migration, juvenile salmonids are, according to this hypothesis, imprinted on odours associated with their home river, and as adults they use these odour memories for homing (Hasler and Scholz, 1983; Dittman and Quinn, 1996; McCormick 
et al., 1998). Bett and Hinch (2015) introduced a new hypothesis (the hierarchical navigation hypothesis), which unifies and expands upon these two hypotheses, positing that migrating adults rely on three types of cues in a hierarchical fashion: imprinted cues, conspecific cues, and non-olfactory environmental cues. These cues can, however, be exerted only close to the coast, near the natal river.

Seasonal movements between ocean feeding areas and spawning areas are characteristic of salmonid life histories (Klemetsen et al., 2003; Hayes and Kocik, 2014). The feeding areas of Atlantic salmon cover large areas of the North Atlantic Ocean, Labrador Sea, Barents Sea, and Baltic Sea, but may differ among populations (Dadswell et al., 2010; Rikardsen and Dempson, 2011). There is information on some of the open ocean feeding areas of several North American and European Atlantic salmon populations based on recaptures of tagged fish (Jacobsen et al., 2012; Mork et al., 2012; Reddin et al., 2012). However, information on the marine geographic distribution of salmon in the ocean is still lacking, particularly on northern populations (Jensen et al., 1999; Rikardsen et al., 2008; Jensen et al., 2012). Jensen et al. (2011) found more synchronous marine growth between populations originating from rivers in proximity than more distant Atlantic salmon populations. This indicates that Atlantic salmon from northern European rivers stay in other areas than fish from more southern populations and may be distributed further north in the North Atlantic Ocean and Barents Sea (Chittenden et al., 2013a; Jensen et al., 2014). One-sea-winter (1SW) and multi-sea-winter (MSW) temperature selection would distribute individuals of the same population in a north to south gradient even in the same current system, resulting in fish of different ages being in different areas when they mature and start the homeward migration (Dadswell et al., 2010). Hence, salmon of different age groups may use different migration routes.

The objective of the present study was to describe the return migration of 1SW and MSW Atlantic salmon towards the coast and their home rivers. Recaptures of returning adult individuals, tagged as smolts, from two nearby rivers in northern Norway were used to indicate timing, distance, and direction of return migration in coastal waters in relation to their home rivers. The spatial distribution of the recaptures was studied by analysing the variation in catch per unit effort (CPUE).

\section{Material and methods}

During 1986-2009, a total of 296563 Atlantic salmon smolts were tagged with individually numbered Carlin tags (Carlin, 1955) and released in the River Halselva (Lat./Lon.: $70.03^{\circ} \mathrm{N} / 22.98^{\circ} \mathrm{E}$, $n=100415$ ) or River Altaelva (Lat./Lon.: $69.97^{\circ} \mathrm{N} / 23.38^{\circ} \mathrm{E}$, $n=190909$ ). Both rivers drain into the inner part of the Alta Fjord, with $18 \mathrm{~km}$ distance between the river mouths (Figure 1). In total, 5239 tagged smolts were towed from the River Altaelva and released in the Alta Fjord. These fish were combined with the fish released in the River Altaelva in the analyses, giving in total 196148 smolts in this group. Some of the smolts $(n=9354)$ were wild fish tagged when they passed a Wolf trap (Wolf, 1951) in the River Halselva. The remaining fish were hatchery-reared smolts from the Talvik hatchery, which were first generation (F1) offspring of wild salmon captured in the River Altaelva. The mean annual number of smolts released was 12356 (range 3134$22002)$.

Of the tagged smolts, 1778 were reported as recaptured. All recaptures with information on recapture location $(n=1611)$ were geographically referenced using Universal Transverse Mercator, zone $33 \mathrm{~N}$. Of these, 86 individuals were recaptured in other areas of the Northern Atlantic Ocean than at the coast of Norway, while 415 were recaptured in fresh water (including the home rivers). The remaining 1110 individuals were recaptured along the coast of Norway during the return migration from the ocean (Figure 2a). Among the coastal recaptures, 657 were caught in bag nets and 286 in bend nets. These 943 recaptures are the primary data used in this study. In addition, 167 individuals were recaptured by trolling line, rod/jig, gillnet, seine, or trawl.

For each fish, the shortest distance "as the fish swims" from the mouth of the river where they were released to the recapture site at sea was estimated by using ArcGIS 10.1 and a $50 \times 50 \mathrm{~m}$ raster derived from a vector map of the Norwegian territorial waters (N-50 series, Norwegian mapping authority). To distinguish between fish captured south of, north of and in the Alta Fjord, directionality was included in the analysis by dividing the recaptures into three groups based on recapture location (Figure 1). For recaptures in the fjord (the municipality of Alta) distances were set to zero, for recaptures north of the fjord distances were given positive values, and for recaptures south of the fjord, distances were given negative values (Figure 1).

When examining the spatial distribution of recaptures, we corrected for the variation in fishing effort. Yearly data on the number of bag nets and bend nets per week for all municipalities in Norway for 1993-2010 were obtained from Statistics Norway (www.ssb.no). Bag nets and bend nets are the two gears commonly used in the Norwegian costal fishery for Atlantic salmon. Only recaptures from bag nets in the period 1993-2010 $(n=415)$ were included in analyses correcting for fishing effort. The reasons for this is that (i) data on fishing effort prior to 1993 is not available, (ii) the bend net fisheries has been subject to numerous restrictions in the stipulations regarding fishing time during the study period, and has since 1997 been restricted to the northernmost county of Norway (Finnmark), and (iii) the unknown differences in catch efficiencies between the gears.

For all municipalities, weekly data on numbers of single and double bag nets in use per week were aggregated to yearly total bag net weeks (Figure 2b). Municipalities further away than the most distant recaptures were excluded from the analysis. The number of double bag nets, where fish can enter from two sides, was multiplied by two to reflect the higher catch efficiency compared with single bag nets, where fish can enter from only one side. For each year and municipality, CPUE was calculated by dividing the number of 1 SW and MSW Atlantic salmon, by the total number of bag net weeks. CPUE was modelled as a function of distance from the release site using a non-parametric smoother. The smoother was fitted using a generalized additive model (GAM) with a quasi-Poisson link function.

To examine if 1 SW and MSW Atlantic salmon differed in spatial distribution of recaptures, data from all years from both bag nets and bend nets were included. This was permissible as the sampling locations were the same for both groups of fish, and hence correction for fishing effort was not required.

All the statistical analyses were done using R v.3.3.1. (R Core Team, 2016), including the GAM package (Hastie, 2016).

\section{Results}

The coastal recaptures of the returning Atlantic salmon $(\mathrm{n}=943)$ covered a large geographical area of the Norwegian coastline. The southernmost recapture was in the municipality of Smøla (Lat./ 


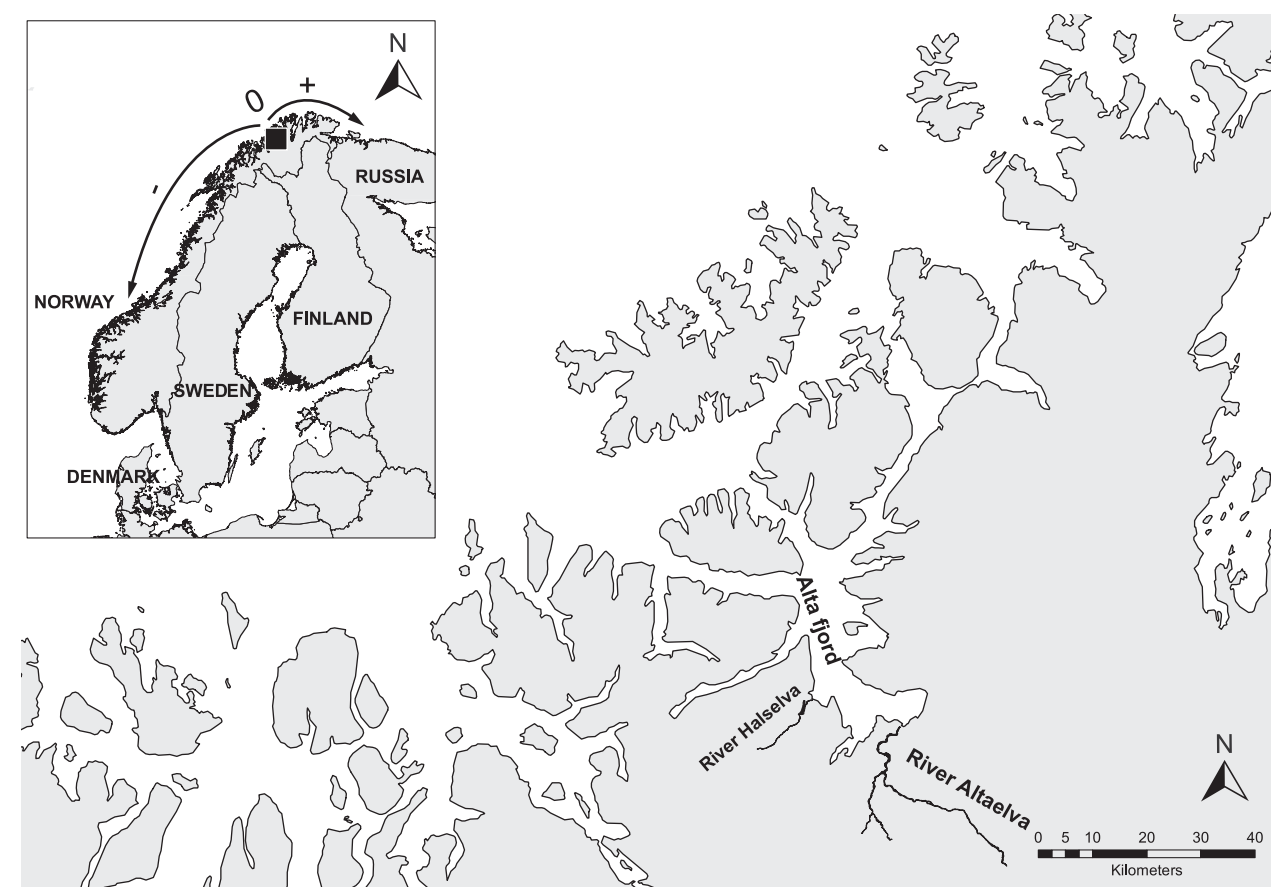

Figure 1. Map of the study area where individually numbered Carlin-tagged Atlantic salmon were released. Alta municipality is indicated with a black square. To distinguish between fish captured south and north of the Alta Fjord, recaptures north of the fjord were given as positive distances and recaptures south of the fjord as negative distances.

Lon.: $63.52^{\circ} \mathrm{N} / 07.97^{\circ} \mathrm{E}$ ), a distance of $1115 \mathrm{~m}$ from the release site. The north-easternmost recapture was in the municipality of Vadsø (Lat./Lon.: $70.11^{\circ} \mathrm{N} / 29.32^{\circ} \mathrm{E}$ ), $519 \mathrm{~km}$ from the release site (Figure 2a). The number of recaptures decreased with distance from the Alta Fjord. In fact, 54\% (513 of 943) of all coastal recaptures were within the municipality of Alta, close to the rivers where they were released. Distances for the coastal recaptures ranged from $674 \mathrm{~m}$ to $1115 \mathrm{~km}$ (mean: $109 \mathrm{~km}$, median: $34 \mathrm{~km}$, Figure 3) from the release site.

CPUE of returning adult Atlantic salmon decreased with distance both to the north and south of the Alta Fjord. The trend was more variable southwards, with smaller increases in CPUE in Vesterålen and the Vefsn Fjord, 469 and $762 \mathrm{~km}$ south of the release site (Figures $2 \mathrm{c}$ and 4 ).

The influence of distance on CPUE decreased from a maximum at the release site in a symmetric manner both to the north and south during the first $250 \mathrm{~km}\left[\mathrm{GAM}: F_{(\sim 9,4200)}=7.91, p<\right.$ 0.001]. Although the effect of distance northwards continued to drop and fell below zero at $400 \mathrm{~km}$ from the release site, the effect of distance southwards fluctuated around a low positive level until $900 \mathrm{~km}$ from the release site (Figure 4).

The MSW Atlantic salmon entered the fisheries earlier than the 1SW fish (Two-sample Kolmogorov-Smirnov test; $D=0.34, p<$ 0.01 ) (Figure 5). The geographical distribution of coastal recaptures did not differ between 1SW and MSW fish (KolmogorovSmirnov: $D=0.09, p=0.068$ ). Also the mean (Welch t-test: $\mathrm{t}=$ $1.30, p=0.20)$ and the variance (F-test: $F=0.90, p=0.29)$ of the distance between the recapture site and release river did not differ between 1SW and MSW fish. When direction of the recaptures compared with the release site was included in the analyses (negative to the south and positive to the north), there was still no difference between 1SW and MSW Atlantic salmon in terms of mean and variance (Welch t-test: $\mathrm{t}=-1.45, p=0.15$; F-test:
$F=0.96, p=0.64$ ) (Figure 6), but the distribution differed (Kolmogorov-Smirnov, $D=0.10, p=0.04$ ). However, this did not seem related to differences in the north-south distribution between 1SW and MSW fish (Fisher test with three factors: north, south, and in the fjord, $p=0.27$ ).

Of the 415 salmon recaptured in fresh water, 338 were tagged and released in the River Altaelva and 77 in the River Halselva. For salmon from the River Altaelva that were recaptured in fresh water, $91 \%$ (308 of 338) were recaptured in the River Altaelva, resulting in a straying rate of $9 \%$. The 30 fish that strayed from their natal river were recaptured in 16 different rivers (average straying distance from the mouth of the River Altaelva to the river where they were recaptured $198 \mathrm{~km}$, median $163 \mathrm{~km}$, SD 167), of which 9 were recaptured in nearby rivers $(<100 \mathrm{~km}$ away), including Halselva. Most of the recaptures were over $100 \mathrm{~km}$ away (17 of 21), and done in large rivers like the River Reisaelva, Kvænangselva, Børselva, Målselva, Lakselva in Porsanger, Tanaelva, and Vefsna. Recaptures were found up to $788 \mathrm{~km}$ south of Altaelva (River Vefsna) and up to $358 \mathrm{~km}$ north-east (River Tanaelva). Eight recaptures were found in the municipality of Alta, 14 to the south and 8 to the north. The River Reisaelva had the highest number of recaptures $(n=6,162 \mathrm{~km}$ away).

For salmon from the River Halselva that were recaptured in fresh water, $90 \%$ (69 of 77) were recaptured in their home river, resulting in a straying rate of $10 \%$. The remaining eight fish were recaptured in six different rivers (average straying distance from the River Halselva: $110 \mathrm{~km}$, median $27 \mathrm{~km}$, SD 133), of which five were recaptured in nearby rivers $(<100 \mathrm{~km}$ away), including the River Altaelva. The other three recaptures were from the River Reisaelva, Målselva and Tanaelva (all $>100 \mathrm{~km}$ away). The straying rate for both rivers combined was $9 \%$ (38 out of 415 ).

There were 86 reported recaptures in other ocean areas than the coast of Norway, of which 53 had a reported recapture 
(a)

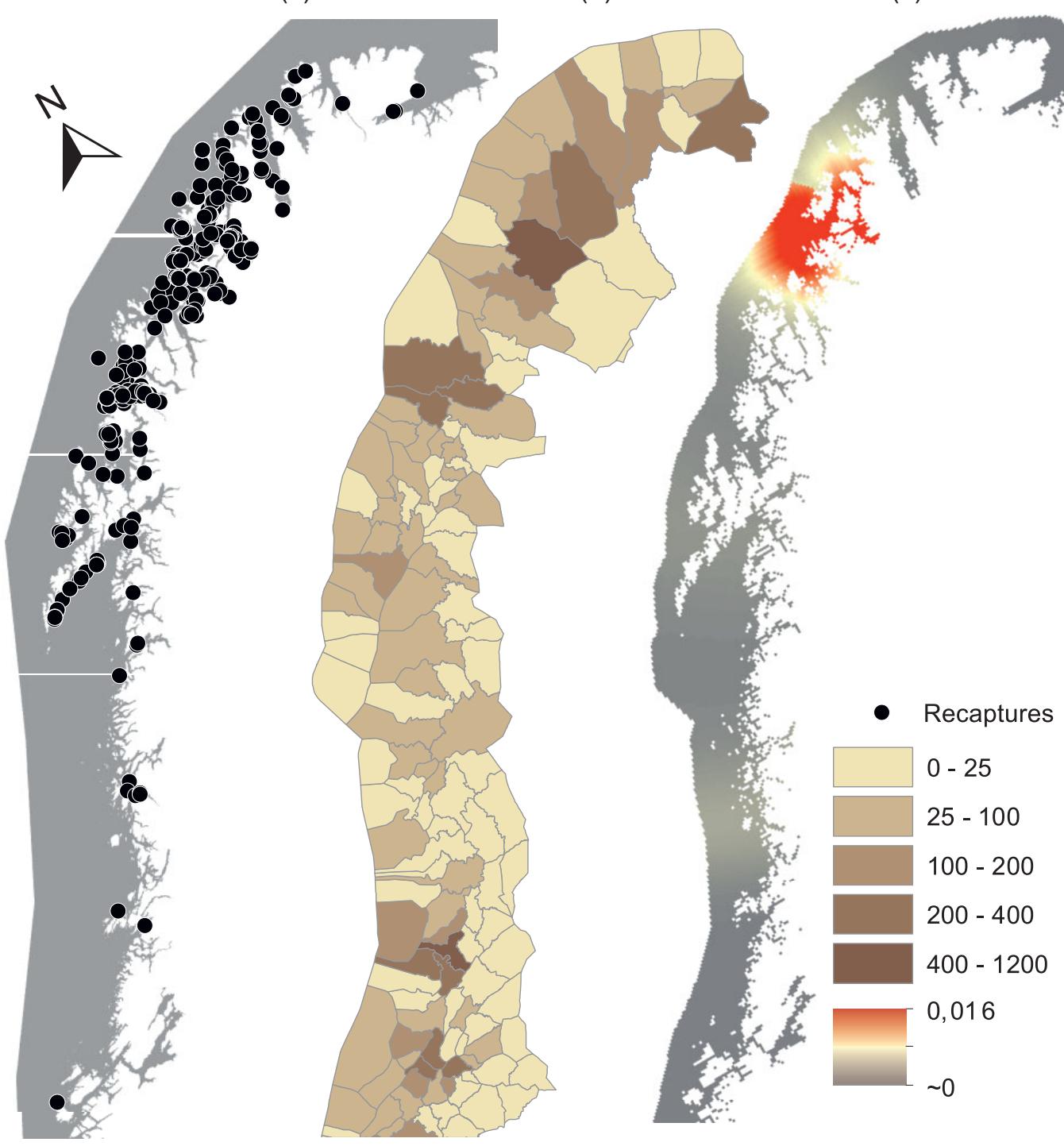

Figure 2. Maps of the coast of northern Norway showing (a) recapture locations (black dots) for returning Atlantic salmon released as smolts during 1988-2010, (b) fishing effort within each municipality, the scale goes from light (minimum: 1 bag net week) to dark (maximum: 1145 bag net weeks), and (c) smoothed data on CPUE of the recaptures, the scale goes from grey (minimum: 1.66e-007) to red (maximum: 0,016). For each year and municipality, CPUE was calculated by dividing the number of 1SW and MSW Atlantic salmon, by the total number of bag net weeks.

location. Of these, 47 were recaptured in the area north of the Faroe Islands, three were recaptured on the south coast of Greenland, two in the Barents Sea and one at Svalbard.

\section{Discussion}

The return migration of Atlantic salmon from ocean feeding areas is divided into two phases; the first phase involve a crude navigation towards the coast (Petersson, 2016), and the second phase is a more accurate navigation to locate their home river (Bett and Hinch, 2015). This study contributes to a better understanding of the first phase. The large geographical range of recaptures along the Norwegian coast found in this study may indicate a rather inaccurate migration from the ocean towards the coast, with individuals approaching from $1115 \mathrm{~km}$ south of their home river to $519 \mathrm{~km}$ north-east. However, despite this dispersal pattern, our results show that a large proportion of fish enter the coast close to their home river, as more than half of the coastal recaptures were reported from local waters in the municipality of Alta. Hence, the results indicate a relatively accurate navigation towards the coast for the majority of individuals. For these fish, the recapture pattern was perpendicular to the main Norwegian coastal current, which suggests that rheotaxis was not used as a navigation cue. In accordance with Hansen et al. (1993), the directional symmetry of recaptures around the Alta Fjord strengthens the evidence that the coastal phase of the return migration of Atlantic salmon is neither passive nor guided by currents alone. The recapture locations imply that salmon moved both with (northward) and against (southward) the coastal current, which further suggests the cues used for homing were not associated with the coastal current itself (Hansen et al. 1993). It has been 


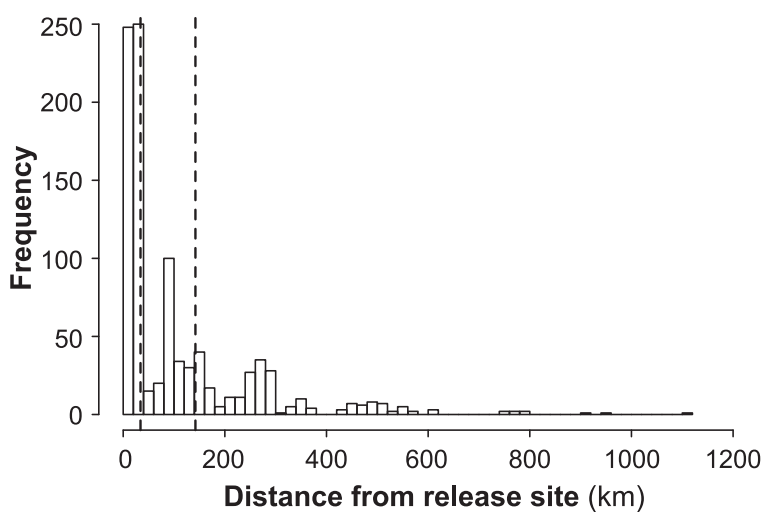

Figure 3. Histogram showing the distance from between the release site and the recapture site for Atlantic salmon recaptured along the Norwegian coast for 1988 to 2010. Dotted vertical lines represent the median and third quantile, respectively.

suggested that salmon use geomagnetism, by detecting the Earth's magnetic field and use this as a directional cue to navigate in open sea (Lohmann et al., 2008). The alternative hypotheses that they use geomagnetism, a map-and-compass system or imprinted cues could not be rejected.

The returning Atlantic salmon were recaptured at the coast both north and south of the home rivers, with the highest CPUE within $200 \mathrm{~km}$ north and south of the release site, and a symmetrical decrease in CPUE in both directions. The most distant recaptures were further away in the southern than the northeastern direction, which may partly be due to the north-eastern Russian border, and a lower likelihood of recaptures being reported from Russia than within Norway. The large geographical range of the recaptures, both to the north and south of the home rivers, indicates fish were entering the coast either north of, south of or directly into the Alta Fjord, possibly as a result of returning from different feeding areas in the Atlantic Ocean. The fact that salmon from the study rivers use feeding areas both in southern and northern parts of the North Atlantic Ocean was confirmed by the oceanic recaptures. These recaptures were located north of the Faroe Islands (majority), in the Barents Sea, at the south coast of Greenland and Svalbard (the recaptures in the Barents Sea and at Svalbard are previously reported by Rikardsen et al. 2008). Little is known about where salmon from the River Altaelva and the River Halselva feed in the ocean, but some studies confirm what we found. Jensen et al. (2014) found, by use of genetic markers, that the majority of salmon captured at Svalbard were assigned to salmon rivers in Finnmark. Finnmark is the northernmost county of Norway, where our study rivers are located. Studies of previous spawners from the River Altaelva, tagged with data storage tags as kelts, indicated the marine distribution of these fish extended from the Greenland Sea, north to Svalbard, and into the eastern Barents Sea (Chittenden et al., 2013a, b). In the Faroe waters, salmon from most populations of the species' distribution range seem to be present, but likely at different times of the year and in different proportions (Hansen and Jacobsen, 2003; Jacobsen et al., 2012; Gilbey et al., 2017). Thus, individual salmon from our study rivers may travel to different ocean areas, but individuals may also move over large areas during their ocean migration, as shown in Gudjonsson et al. (2015) and Strøm et al. (2017). Dadswell et al. (2010) suggested the marine migration routes of Atlantic salmon depend on large-scale current systems, especially the North Atlantic Subpolar Gyre.

The distribution of recaptures from fisheries is highly influenced by the distribution and intensity of fishing effort. Recoveries are obtained only at locations where fishing gears are located, but the spatial distribution of the fishery can be a response to the arrival of salmon (Miller et al., 2012). The main fisheries for Atlantic salmon in the Atlantic Ocean during our study period occurred north of the Faroe Islands and west/southwest of Greenland (Scarnecchia et al., 1991). There are almost no fisheries that target Atlantic salmon in other ocean areas, and therefore recapture rates of tagged fish from these areas are low. The large proportion of tagged fish recaptured north of the Faroe Islands in the present study does not necessarily indicate that most of the tagged salmon migrated to this area, but rather reflects the large fishing effort in this area compared with most other ocean areas. Recaptures of tagged salmon in other open ocean areas were often a result of bycatch in fisheries targeting other fish species (Rikardsen et al., 2008). Coastal recaptures in our study were based on catches in bag nets and bend nets. These fishing gears target salmon that have been used at fixed locations along most of the Norwegian coastline, but with a varying effort among areas. Hence, the number of recaptures will be overrepresented in areas with high densities of fishing gear. To correct for this, CPUE estimates of recaptures were used to obtain representative information on presence of tagged salmon in different coastal areas.

1SW and MSW Atlantic salmon may use different ocean areas (Scarnecchia et al., 1989; Spares et al., 2007; Dadswell et al., 2010), and therefore return from different directions and at different times in the season. In our study, no significant differences in spatial distribution of recaptures were found between 1SW and MSW fish. Thus, the geographic pattern of recaptures did not indicate that they returned from different directions and ocean feeding areas. However, MSW fish were recaptured earlier in the year than the $1 \mathrm{SW}$ fish. This is in accordance with previous studies, showing a typical pattern that MSW salmon return to coastal waters earlier than 1SW salmon (Dunkley, 1986; Shearer, 1992; Jonsson et al., 2003). The reasons for the earlier return of MSW over 1SW salmon are not known, but could be due to MSW salmon residing in ocean areas closer to the river and therefore having a shorter return migration, or simply due to MSW salmon being larger and faster swimmers. Another possible explanation is that MSW salmon return earlier than 1SW salmon as a consequence of a trade-off between added percent body mass and increased mortality risk in the ocean compared with fresh water, causing large fish to return earlier than small fish. In general, Atlantic salmon in Norway enter the rivers from May to October, and spawn in October to January (Klemetsen et al., 2003; Quinn et al., 2015). The advantages of this behaviour are not well understood, especially considering the loss of feeding opportunities at sea (Fleming, 1996; Thorstad et al., 2008). A reason for early arrival at spawning grounds is that it may provide a competitive advantage in acquiring spawning sites and partners, and it might be that this advantage is most pronounced for large males, which fight for access to females on the spawning grounds. In the River Altaelva $75 \%$ of the MSW salmon are females and $96 \%$ of the 1SW are males (Ugedal et al., 2008), so the earlier return of MSW salmon could also be explained by females having an increased advantage of an early return over small males. If the development of eggs reduces the swimming capacity during upstream 

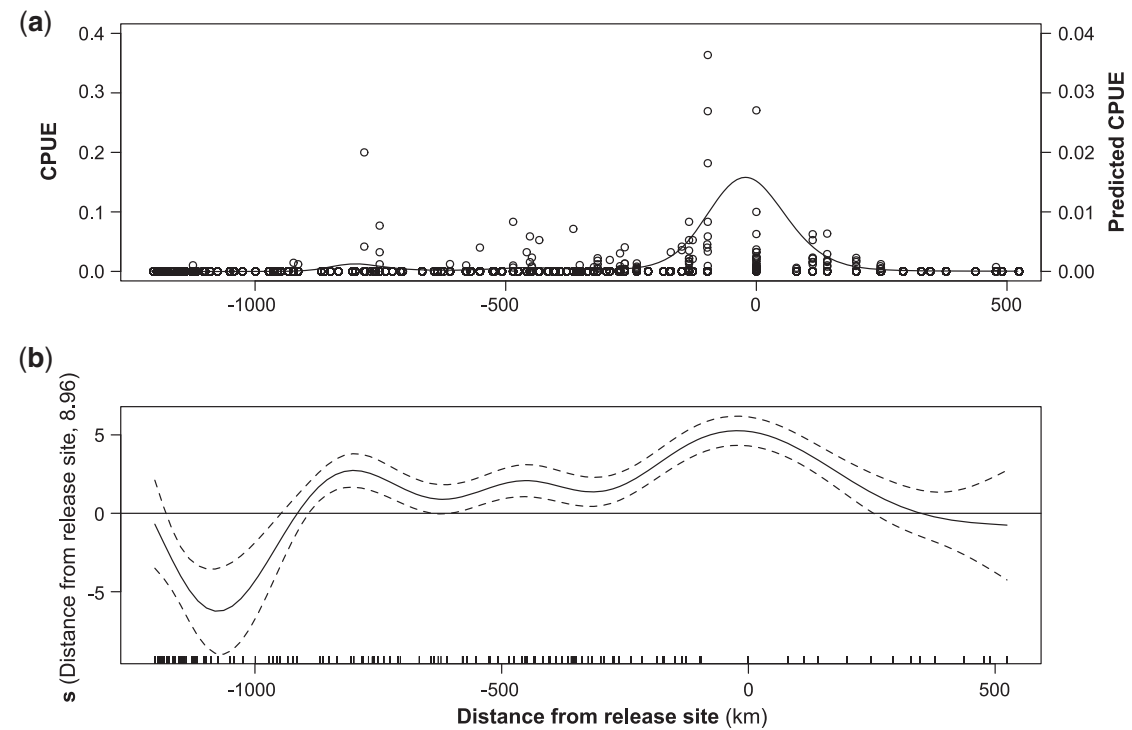

Figure 4. (a) Relationship between the distance from the release site and CPUE of tagged Atlantic salmon (dots), and predicted CPUE from the GAM (solid line). (b) Smoothed effect of distance on CPUE of tagged Atlantic salmon estimated using GAM. The $y$-axis represents the average contribution of the predictor variable on a logit scale. Degrees of freedom are shown in parentheses on the $y$-axis, and etchings on the $x$-axis indicate location of data points (i.e. municipalities). Negative values on the $x$-axis indicate a southern direction from the release site and positive values a northern direction. Data are based on individuals recaptured in 1993-2010. For each year and municipality, CPUE was calculated by dividing the number of 1SW and MSW Atlantic salmon, by the total number of bag net weeks.
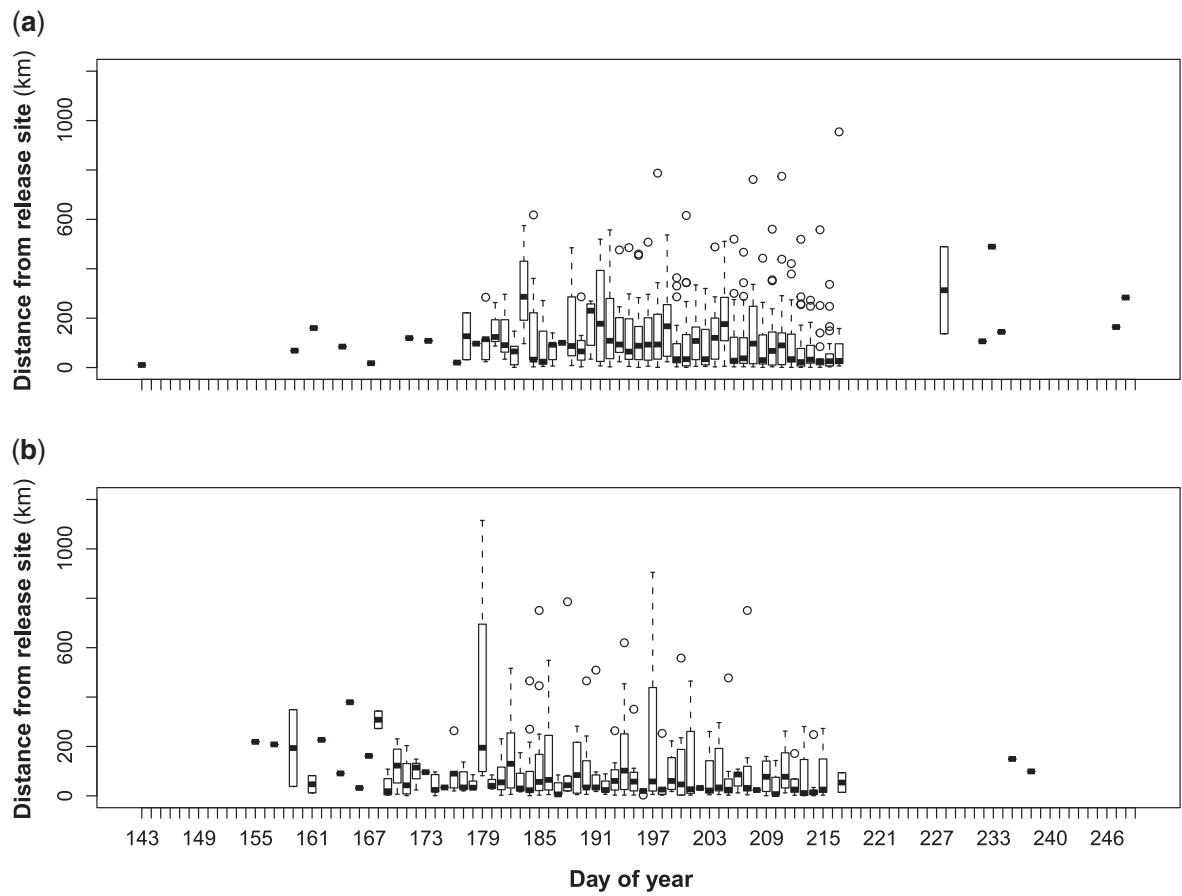

Figure 5. Relationship between the distance from the recapture location to the release site and recapture date (day of the year) for (a) 1SW and (b) MSW Atlantic salmon tagged and released in the River Altaelva and the River Halselva in the period 1988 to 2010 . Both bend net and bag net recaptures are included. The whiskers span to the most extreme data point (no $>1.5$ times the interquartile rage). The bold horizontal line is the median and the bottom and top of the box represent the 25 th and 75 th percentiles.

migration, it could be advantageous for females to return earlier than males (Thorstad et al., 2008).

Atlantic salmon are known for their accurate homing to their natal river, although a small percentage of the population strays to other rivers. Of riverine recaptures, we found $9 \%$ were recaptured in another river than their home river during the recreational fisheries in Norway, which is a larger straying rate than recorded in earlier studies (3-6\%; Stabell, 1984; Potter and 
(a)
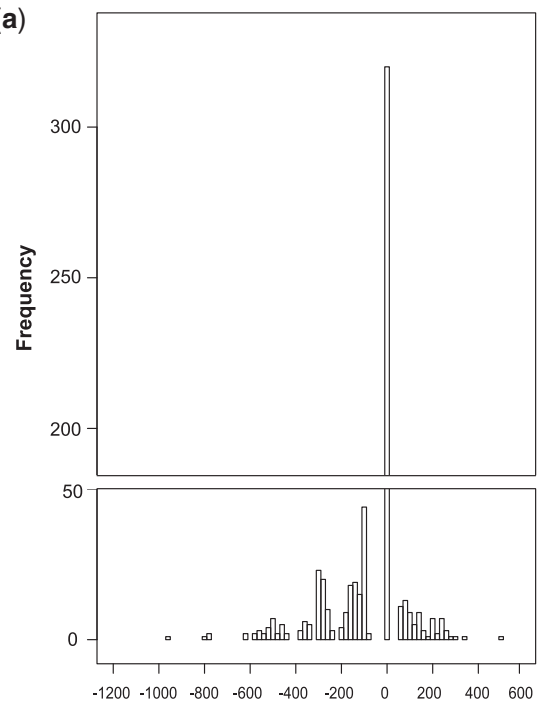

(b)
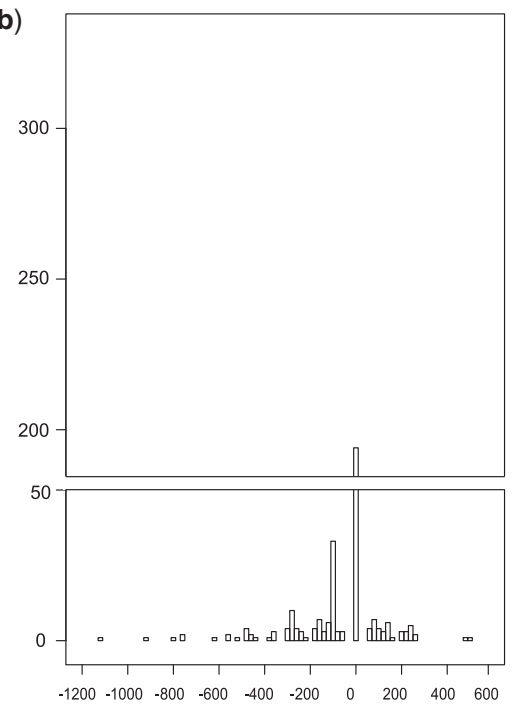

Distance from release site $(\mathrm{km})$

Figure 6. Histogram showing number of Atlantic salmon recaptured as (a) 1SW and (b) MSW fish with distance and direction from the release site. Negative values indicate recaptures south of the Alta Fjord, positive values recaptures north of the fjord and zero values recaptures within the fjord.

Russell, 1994; Jonsson et al., 2003). The larger straying rate might be because most of the fish in this study were hatchery-reared salmon, which may have less accurate homing than wild salmon (Stabell, 1984). However, Potter and Russell (1994) did not find a difference in straying rate between hatchery-reared and wild Atlantic salmon in north-east England. The higher straying rate might also be a consequence of the fact that the riverine recaptures in our study were caught during the recreational salmon fisheries, which takes place in from July through August in most Norwegian rivers. This opens for the possibility that they can have been intercepted in transit to natal rivers, and thus give a higher rate than the true straying rate. Most of the strays in the present study were recaptured in nearby rivers $(<100 \mathrm{~km}$ away), or in relatively large rivers, if further away.

In conclusion, the results in this study demonstrated large individual variation in where the returning Atlantic salmon entered the coast in relation to their home river. This could be because individuals were residing in different ocean areas when feeding, and thus returning to the Norwegian coast over a large geographical area. The results indicated a relatively accurate navigation towards the coast for the majority of the individuals - and also to the home river, with few fish being recaptured in other rivers.

\section{Acknowledgements}

The authors wish to thank station manager Frode Løvik and the staff of the Talvik Research Station for invaluable assistance in smolt production, tagging and releases of fish, and the fishers and Cedar Chittenden for input to the study. We would like to thank Statistics Norway for providing the catch statistics, Kari Sivertsen at NINA for formatting the graphics, and Frode Thomassen Singsaas at the NINA library for requiring literature. Financial support was provided by the Norwegian Environment Agency, Alta Laksefiskeri Interessentskap (ALI), Statkraft Energy AS, and the Norwegian Institute for Nature Research (NINA).

\section{References}

Bett, N. N., and Hinch, S. G. 2015. Olfactory navigation during spawning migrations: a review and introduction of the Hierarchical Navigation Hypothesis. Biological Reviews, 91: 728-759.

Carlin, B. 1955. Tagging of salmon smolts in the river Lagan. Report of the Institue of Freshwater Research Drottningholm, 36: 57-74.

Chittenden, C. M., Fauchald, P., and Rikardsen, A. 2013a. Important open-ocean areas for northern Atlantic salmon (Salmo salar) as estimated using a simple ambient-temperature approach. Canadian Journal of Fisheries and Aquatic Sciences, 70: 101-104.

Chittenden, C. M., Ådlandsvik, B., Pedersen, O. P., Righton, D., and Rikardsen, A. H. 2013b. Testing a model to track fish migrations in polar regions using pop-up satellite archival tags. Fisheries Oceanography, 22: 1-13.

Dadswell, M. J., Spares, A. D., Reader, J. M., and Stokesbury, M. J. W. 2010. The North Atlantic subpolar gyre and the marine migration of Atlantic salmon Salmo salar: the 'Merry-Go-Round' hypothesis. Journal of Fish Biology, 77: 435-467.

Dingle, H. 2014. The Biology of Life on the Move, 2nd edn., Oxford University Press, UK.

Dittman, A. H., and Quinn, T. P. 1996. Homing in Pacific salmon: mechanisms and ecological basis. Journal of Experimental Biology, 199: 83-91.

Dunkley, D. A. 1986. Changes in the timing and biology of salmon runs. In The Status of Atlantic Salmon in Scotland, pp. 20-27. Ed. by D. Jenkins, and W. M. Shearer. I.T.E. Symposium, Huntingdon, UK.

Fleming, I. A. 1996. Reproductive strategies of Atlantic salmon: ecology and evolution. Reviews in Fish Biology and Fisheries, 6: 379-416.

Gilbey, J., Wennevik, V., Bradbury, I. R., Fiske, P., Hansen, L. P., Jacobsen, J. A., and Potter, T. 2017. Genetic stock identification of Atlantic salmon caught in the Faroese fishery. Fisheries Research, 187: 110-119.

Groot, C., and Margolis, L. 1991. Pacific Salmon Life Histories, UBC Press, Vancouver, Canada.

Gross, M. R., Coleman, R. M., and McDowall, R. M. 1988. Aquatic productivity and the evolution of diadromous fish migration. Science, 239: 1291-1293. 
Gudjonsson, S., Einarsson, S. M., Jonsson, I. R., and Gudbrandsson, J. 2015. Marine feeding areas and vertical movements of Atlantic salmon (Salmo salar) as inferred from recoveries of data storage tags. Canadian Journal of Fisheries and Aquatic Sciences, 72: $1-12$.

Hansen, L. P., and Jacobsen, J. A. 2003. Origin and migration of wild and escaped farmed Atlantic salmon, Salmo salar L., in oceanic areas north of the Faroe Islands. ICES Journal of Marine Science, 60: 110-119.

Hansen, L. P., Jonsson, N., and Jonsson, B. 1993. Oceanic migration in homing Atlantic salmon. Animal Behaviour, 45: 927-941.

Hasler, A. D., and Scholz, A. T. 1983. Olfactory Imprinting and Homing in Salmon, Springer-Verlag, Berlin, New York.

Hastie, T. 2016. Gam: Generalized Additive Models. R package version 1.14. https://CRAN.R-project.org/package=gam.

Hayes, S. A., and Kocik, J. F. 2014. Comparative estuarine and marine migration ecology of Atlantic salmon and steelhead: blue highways and open plains. Reviews in Fish Biology and Fisheries, 24: 757.

Jacobsen, J. A., Hansen, L. P., Bakkestuen, V., Halvorsen, R., Reddin, D. G., White, J., O’Maoiléidigh, N. et al. 2012. Distribution by origin and sea age of Atlantic salmon (Salmo salar) in the sea around the Faroe Islands based on analysis of historical tag recoveries. ICES Journal of Marine Science, 69: 1598-1608.

Jensen, A. J., Diserud, O. H., Finstad, B., Fiske, P., and Rikardsen, A. H. 2015. Between-watershed movements of two anadromous salmonids in the Arctic. Canadian Journal of Fisheries and Aquatic Sciences, 72: 855-863.

Jensen, A. J., Fiske, P., Hansen, L. P., Johnsen, B. O., Mork, K. A., and Næsje, T. F. 2011. Synchrony in marine growth among Atlantic salmon (Salmo salar) populations. Canadian Journal of Fisheries and Aquatic Sciences, 68: 444-457.

Jensen, A. J., Karlsson, S., Fiske, P., Hansen, L. P., Østborg, G. M., and Hindar, K. 2014. Origin and life history of Atlantic salmon Salmo salar near their northernmost oceanic limit. Canadian Journal of Fisheries and Aquatic Sciences, 71: 1740-1746.

Jensen, A. J. Ó., Maoiléidigh, N., Thomas, K., Einarsson, S. M., Haugland, M., Erkinaro, J., Fiske, P. et al. 2012. Smolt age and fine-scale marine growth of Atlantic salmon post-smolts in the Northeast Atlantic. ICES Journal of Marine Science, 69: 1668-1677.

Jensen, A. J., Zubchenko, A. V., Heggberget, T. G., Hvidsten, N. A., Johnsen, B. O., Kuzmin, O., Loenko, A. A. et al. 1999. Cessation of the Norwegian drift net fishery: changes observed in Norwegian and Russian populations of Atlantic salmon. ICES Journal of Marine Science, 56: 84-95.

Jonsson, B., Jonsson, N., and Hansen, L. P. 2003. Atlantic salmon straying from the River Imsa. Journal of Fish Biology, 62: 641-657.

Keefer, M. L., and Caudill, C. C. 2014. Homing and straying by anadromous salmonids: a review of mechanisms and rates. Reviews in Fish Biology and Fisheries, 24: 333-368.

Klemetsen, A., Amundsen, P.-A., Dempson, J. B., Jonsson, B., Jonsson, N., O'Connell, M. F., and Mortensen, E. 2003. Atlantic salmon Salmo salar L., brown trout Salmo trutta L. and Arctic charr Salvelinus alpinus (L.): a review of aspects of their life histories. Ecology of Freshwater Fish, 12: 1-59.

Lohmann, K. J., Putman, N. F., and Lohmann, C. M. F. 2008. Geomagnetic imprinting: A unifying hypothesis of long-distance natal homing in salmon and sea turtles. Proceedings of the National Academy of Sciences of the United States of America, 105: 19096-19101.

McCormick, S. D., Hansen, L. P., Quinn, T. P., and Saunders, R. L. 1998. Movement, migration, and smolting of Atlantic salmon (Salmo salar). Canadian Journal of Fisheries and Aquatic Sciences, 55(Suppl. 1): 77-92.
Miller, A. S., Sheehan, T. F., Renkawitz, M. D., Meister, A. L., and Miller, T. J. 2012. Revisiting the marine migration of US Atlantic salmon using historical Carlin tag data. ICES Journal of Marine Science, 69: 1609-1615.

Mork, K. A., Gilbey, J., Hansen, L. P., Jensen, A. J., Jacobsen, J. A., Holm, M., Holst, J. C. et al. 2012. Modelling the migration of post-smolt Atlantic salmon (Salmo salar) in the Northeast Atlantic. ICES Journal of Marine Science, 69: 1616-1624.

Nordeng, H. 1977. A pheromone hypothesis for homeward migration in anadromous salmonids. Oikos, 28: 155-159.

Petersson, E. 2016. Homing and Timing of Reproduction. In Evolutionary Biology of the Atlantic Salmon, pp. 44-58. Ed. by T. Vladic, and E. Petersson. CRC Press, Boca Raton, London, New York.

Potter, E. C. E., and Russell, I. C. 1994. Comparison of the distribution and homing of hatchery-reared and wild Atlantic salmon, Salmo salar L., from north-east England. Aquaculture and Fisheries Management, 25 (Suppl. 2): 31-44.

Quinn, T. P., McGinnity, P., and Reed, T. E. 2015. The paradox of "premature migration" by adult anadromous salmonid fishes: patterns and hypotheses. Canadian Journal of Fisheries and Aquatic Sciences, 73: 1015-1030.

R Core Team 2016. R: a language and environment for statistical computing. R Foundation for Statistical Computing. http://www. R-project.org, Vienna, Austria.

Reddin, D. G., Hansen, L. P., Bakkestuen, V., Russell, I., White, J., Potter, E. C. E., Dempson, J. B. et al. 2012. Distribution and biological characteristics of Atlantic salmon (Salmo salar) at Greenland based on the analysis of historical tag recoveries. ICES Journal of Marine Science, 69: 1589-1597.

Rikardsen, A. H., and Dempson, J. B. 2011. Dietary life-support: the food and feeding of Atlantic salmon at sea. In Atlantic Salmon Ecology, pp. 115-143. Ed. by Ø. Aas, S. Einum, A. Klemetsen, and J. Skurdal. Blackwell publishing Ltd., Oxford.

Rikardsen, A. H., Hansen, L. P., Jensen, A. J., Vollen, T., and Finstad, B. 2008. Do Norwegian Atlantic salmon feed in the northern Barents Sea? Tag recoveries from 70 to $78^{\circ}$ N. Journal of Fish Biology, 72: 1792-1798.

Scarnecchia, D. L., Isaksson, A., and White, S. E. 1989. Effects of oceanic variations and the West Greenland fishery on age at maturity of Icelandic west coast stocks of Atlantic salmon (Salmo salar). Canadian Journal of Fisheries and Aquatic Sciences, 46: 16-27.

Scarnecchia, D. L., Ísaksson, Á., and White, S. E. 1991. Effects of the Faroese long-line fishery, other oceanic fisheries and oceanic variations on age at maturity of Icelandic north-coast stocks of Atlantic salmon (Salmo salar). Fish Research, 10: 207-228.

Secor, D. H. 2015. Migration Ecology of Marine Fishes, JHU Press, Baltimore, Maryland, USA.

Shearer, W. M. 1992. The Atlantic Salmon: Natural History, Exploitation and Future Management. Fishing News Books, Oxford.

Spares, A. D., Reader, J. M., Stokesbury, M. J. W., McDermott, T., Zikovsky, L., Avery, T. S., and Dadswell, M. J. 2007. Inferring marine distribution of Canadian and Irish Atlantic salmon (Salmo salar L.) in the North Atlantic Ocean from tissue concentrations of bioaccumulated caesium-137. ICES Journal of Marine Science, 64: 394-404.

Stabell, O. B. 1984. Homing and olfaction in salmonids: a critical review with special reference to the Atlantic salmon. Biological Reviews, 59: 333-388.

Strøm, J. F., Thorstad, E. B., Chafe, G., Sørbye, S. H., Righton, D., Rikardsen, A. H., and Carr, J. 2017. Ocean migration of pop-up satellite archival tagged Atlantic salmon from the Miramichi River in Canada. ICES Journal of Marine Science, 74: 1356-1370.

Thorpe, J. E. 1988. Salmon migration. Science Program (Oxford), 72: 345-370.

Thorstad, E. B., Økland, F., Aarestrup, K., and Heggberget, T. G. 2008. Factors affecting the within-river spawning migration of Atlantic salmon, with emphasis on human impacts. Reviews in Fish Biology and Fisheries, 18: 345-371. 
Ueda, H. 2012. Physiological mechanisms of imprinting and homing migration in Pacific salmon Oncorhynchus spp. Journal of Fish Biology, 81: 543-558.

Ugedal, O., Næsje, T. F., Thorstad, E. B., Forseth, T., Saksgård, L., and Heggberget, T. G. 2008. Twenty years of hydropower regulation in the River Alta: long-term changes in abundance of juvenile and adult Atlantic salmon. Hydrobiologia, 609: 9-23.

Wolf, P. A. 1951. A trap for the capture of fish and other organisms moving downstream. Transaction of the American Fisheries Society, 80: 41-45.

Handling editor: David Secor 